\title{
Reconstruction of Values in Children Songs (Dolanan) at North Sumatera Toward Building Children Work Ethics and Character
}

\author{
Daulat Saragi \\ Lecturer of Fine Arts Education \\ Language and Arts Faculty of Universitas Negeri Medan \\ Medan, Indonesia \\ saragios@yahoo.co.id
}

\begin{abstract}
Singing while playing is one of media to build children character orally. Children songs (dolanan) contain values of respect themselves, others, their surrounding, and the creater. The lyrics contain simple words, easy to understand, and sing to accompany their playing. The simplicity in lyrics also contain life philosophy as guidance to appreciate social values, surrounding, and deity. The aim of the study is to rescontruct or rearrange and to interpret the meaning of dolanans to the new perspective in terms of understandable and applicable in daily life. the material objects are lyrics of dolanan. The formal objective is axiology. Research model was explorative and decsriptive qualitative. The source of data were library research and filed research. The data were analyzed by using philosophy hermeneutic method through the symbolic interpretative qualitative method, historical approach and verstehen. The data were displayed through interpretative descriptive toward the conclusion inductively and deductively. The result showed that sing dolanan at playing time contain values of togetherness, honesty, spirit, persistence, tolerance, educational, appreciation, society, environment, and deity. By doing reconstruction for dolanan in playing for children, will revitaize the spirit values of children work ethics and their characteristic.
\end{abstract}

Keywords : Values; dolanan; ethnics in North Sumatera; work ethics; character

\section{INTRODUCTION}

The ancestors have kept the moral and character of children through moral messages and life philosophy in lyrics of playing songs that are always sung while playing and joking. Now we are ignorant of the wisdom of these ancestors so that children and youth are ensnared in the hustle and bustle of entertainment that offers dreams and lies, so it is feared that someday Indonesia will lose a generation that has a good work ethic and character.

The purpose of this study is to rediscover and document the philosophical values contained in playing songs of children from North Sumatra's ethnic. Scientifically packaging the ethical and moral values contained in the lyrics of playing songs of children into academic texts so that they can contribute to the development of children's character and work spirit (work ethic) which has been inherited by the ancestors from the beginning.

This research wants to restore the values of character and spirit of life of children from North Sumatra's ethnic such as messages and moral teachings in those lyrics of playing songs of children. These values are the building blocks of character and work ethic so that later a young generation that is strong and has good character can be created as a supporting pillar of an advanced and dignified Indonesian nation.

\section{LITERATURE REVIEW}

\section{A. Definition of Playing Song}

The playing song (lagu dolanan) is a song accompanying children's play. The playing song is one of the art and literary media to educate and convey various messages of values to children that are carried out while playing. This term (lagu dolanan) comes from the Javanese people called tembang dolanan, which are songs or poems of literature sung while playing in the yard.

In the Batak Toba community, activities like this were carried out by children in the light of the full moon. In the Batak Toba language it is called martumba (a kind of folk dance performed while singing) and is done in the village (huta) yard. Song poems that contain moral advice and teachings are sung while playing in groups with jokes. Usually the playing songs can be combined with a variety of traditional games or can also be sung alone without a game. With the accompaniment of simple music and exciting footsteps and applause, playing songs became very popular with children of that time.

Ignorance or unwillingness of adults to teach the playing songs to their children makes the loss of knowledge about lyrics of playing songs full of value and meaning. The playing songs that are packaged in children's games can be used as a means to educate children's behavior, especially when children's songs are increasingly scarce. 


\section{B. Definition of Work Ethic}

In Kamus Besar Bahasa Indonesia (a complete Indonesian dictionary), ethos is a life view that is typical of a social group, dominant views or traits of a race or class culture. The work ethic is a work spirit that is a characteristic and belief of a person or group.

According to Webster's dictionary, ethos is defined as a belief that serves as a guide to the behavior of a person, a group, or an institution (guiding the belief of a person, a group or an institution). According to Usman Pelly, the work ethic is an attitude that arises on one's own will and awareness based on a system of cultural value orientation towards work. The work ethic has the basis of cultural values which are the cultural values that shape each individual's work ethic.

History proves that a developed country and continues to race with high technology / information basically starts with a very strong work ethic to succeed. Thus it cannot be ignored that the work ethic is a part that deserves attention in the success of a great country. Both companies and government institutions have proven that a militant work ethic is one of the impacts of the success of the company or department. A person's work ethic is closely related to his personality, behavior, and character.

The work ethic of a tribe or nation is built from its own culture; the work ethic of the Japanese people is different from the work ethic of Indonesians because their cultural basis is different. Japan's view of life that is different from other countries makes this country grow fast. The work ethic of a person or individual is closely related to his personality, behavior, and character. The work ethic of the Batak tribe is different from the Javanese and Asmat tribes in Papua, because they have different cultural backgrounds.

\section{Character as a Positive Quality}

Character is more about moral values. Chaplin in Said, [1] said that the character or behavior, heart, mind, nature is a quality or trait that remains constant and eternal that can be used as a characteristic to identify a person, an object or an event.

Character is the nature, behavior, morals, or personality of a person formed from the results of internalization of various virtues that are believed and used as a basis for the way of seeing, thinking, acting, and acting [2]. Virtue consists of a number of values, morals, and norms, such as honesty, courage to act, trustworthy, and respect for others. A person's interaction with others fosters the character of society and nation. Therefore, the development of national character can only be done through the development of individual character. However, because humans live in certain social and cultural environments, individual character development can only be carried out in the social and cultural environment concerned.

The only way to build the nation's character is through education. Education is a process of enculturation, functioning to pass on past values and achievements to future generations. These values and achievements are the pride of the nation and make the nation known by other nations.
Character is defined as a typical and individual way of thinking and behaving to live and cooperate in the scope of family, community, nation and state. Individuals with good character are individuals who can make decisions and are ready to be responsible for any consequences of their decisions. Character can be regarded as the values of human behavior that relate to God Almighty, oneself, fellow human beings, environment and nationality manifested in thoughts, attitudes, feelings, words and deeds based on the norms of religion, law, manners, culture, customs, and aesthetics.

Character education is closely related to the appreciation of literary works, where these works can act as a means of introducing the values to be instilled in students, such as the values of honesty, responsibility, love for the social environment, virtue, and other noble values. [3]

\section{Definition of Reconstruction}

What is meant by reconstruction in this study is an effort to bring back or to restore as before, to rearrange or redraw what was already there. Thus reconstruction is an attempt to bring back philosophical, ethical and moral values contained in lyrics of playing songs, or songs sung by children while playing.

At first glance the song of the child while playing just as a joke, but the joke quickly attached to the heart of everyone who sang it. Lyrics of playing songs contain moral messages and advice to live a life of mutual respect and protect nature, the environment and the glorification of God. Through the lyrics of these songs, children are inspired by these moral messages so that they can live the messages or advice contained in the poem.

\section{E. Definition of Value, and Moral Value or Ethics}

Ethics and morals relate to values, and Axiology is a philosophy that investigates the nature of values. [4] Max Scheler uses a phenomenological approach to reveal the essence of value, namely the way to philosophize reveals and captures values intuitively, face to face. Value is the a priori basis of intentional object emotions of feeling. Even though the mind is open to it, the value is directly given to the intentionality of feeling as the color is given to vision. Some branches of knowledge that examine the essence of values are as follows: Epistemology is concerned with the nature of truth, Ethics is concerned with the nature of goodness (morality), and Aesthetics are concerned with the nature of beauty. [5]

Axiology investigates broader statements about the value of "truth", "goodness" and "beauty" itself. Ethics and morals are studies of values. Values according to their essence are found by humans ahead of their sensory experience, and a priori are captured by humans from the world of values through their emotional feelings. The existence of a value does not depend entirely on the understanding of the subject, this means that the value cannot change. Value is absolute, not required by action, does not regard its natural existence, historically, socially, biologically, or purely individuals. It's 
just that our knowledge of values is relative, while the value itself is not relative. [6]

Kindness, for example, is absent because of itself, as if floating in the air, but manifesting in behavior, nature, character of humans and so on. [7] Truth does not depend on individual opinion, but depends on the objectivity of the fact: therefore, it is not strengthened or weakened by democratic procedures for counting votes. Likewise with the case of value, the opinions of people with low taste do not reduce the beauty of a work of art. That value does not add reality or substance to objects, but only value. That value is not an object or an element of an object, but a quality characteristic, a sui generis possessed by a particular object that is said to be good.

Ethics is the science of what is usually done or the knowledge of customs [8]. The word that is close to ethics is moral (Latin: mos; mores) which means also habituality or customs, so the etymology of the word 'ethics' is the same as the etymology of the word 'moral' because both come from words that mean customs.

\section{F. Conditions of the North Sumatra Community}

North Sumatra is located between three provinces, namely; Nangroe Aceh Darusalam, Riau and West Sumatra. Of the 10 provinces on the island of Sumatra, North Sumatra was recorded as the largest province consisting of 25 Regencies and 8 Municipalities. The native population of North Sumatra consists of 8 ethnic groups, but now has been inhabited by various ethnic groups from the archipelago. The North Sumatra native tribe consists of the Batak Tribe which is further divided into 6 sub-tribes namely: Batak Toba, Batak Karo, Batak Pakpak or Dairi, Batak Mandailing and Angkola or Sipirok, and Batak Simalungun. The other two tribes are Malay and Nias [9].

The existence of Malay tribe is called Deli Malay, because Malay tribes are also widely found in other Provinces, such as Riau, South Sumatra and Bengkulu. The Nias tribe is a bit different because geographically this tribe lives far outside the island of Sumatra and is separated by the Indian Ocean in the West of Sumatra.

Anthropologists write that North Sumatra has inhabited many immigrant tribes from within its own country such as, Java, Minang, Aceh, Sunda, Madura, and also from other countries such as China, India (Tamil and Punjabi), Pakistan and Arabia. Heterogeneity of North Sumatra brings blessings with the mixing of cultures so that it can lead to a high character and work ethic.

In a previous study I conducted entitled Revealing Pedagogical Values and Moral Teachings Contained in the Meanings of Traditional Houses of Simalungun Batak Traditional Ornaments As a Contribution to National Character Education, Saragi [10], it was concluded that through Simalungun traditional house ornament motifs, expectations, ideals and advice are conveyed so that later young people can live more meaningfully and wisely. Furthermore, it was explained in the conclusion that ornamental motifs contained educational values and moral values inherited from their ancestors.

Furthermore, in the Proceedings of the National Seminar at the UNJ FBS entitled, Revealing the Meaning of Traditional Ornament Philosophy of 8 North Sumatran ethnic groups, [11] Saragi found that ethnic tribal house ornament motifs in North Sumatra contained philosophical values as local wisdom that contributed to the policy of the state (nation wisdom). The meaning of the philosophy of each North Sumatra ornament motif can be contributed to the Nusantara Philosophy.

In his research on Pangkur song in Central Java, Sulistyo [12] wrote in his paper "In the current era of globalization, teaching (advice) of morality and character still has relevance and needs to be given to future generations, therefore interpreting Pangkur song is very important. For the younger generation with the advancement of information and technology today, they need to be fortified with the characteristics or teachings of morals and mind [13].

According to Sulistyo, the Pangkur song's effect on the general public contains moral teachings (advice) to function as adhesive glue in integrating families, communities and nations. The wisdom can be learned especially in the young and old generation, which is now marked by the erosion of noble values or their character. People now assume that the younger generation in Indonesia in general lacks respect for traditional values, especially in relation to parents, their politeness fades. Therefore the teachings contained in the Pangkur song can provide a solution, because in the teaching contains advice about how one should keep the virtuous values. Virtue for the Javanese is the basis for human action. Characteristics can shape noble character for humans, especially the younger generation.

Mohammad Alif [14] in the Proceedings of the International Seminar entitled Values in Toys and Games of the People as a Cultural Heritage in Indonesia, wrote "Through the concept of toys and games by knowing themselves and nature, some games teach children to know their God, This is found in games that teach the concept of obedience, awareness and processing of taste, such as in the game of ucing sumput (hide and seek), .... Toys and games create habituation with the same and repetitive stimulus given to children (receptors) which thus teaches children to prepare for their adulthood.

Furthermore Hardiarini [15] reported the results of his research in the Proceedings of the National Seminar that the playing song was "My Village" by R.C. Hardjosoebrata is full of moral values because lyrics and melodies in playing songs express meaning as an educational tool in the form of advice, guidance, respect, love, about good and bad attitudes with jocoseness.

Pudentia [16] Chairperson of the Oral Tradition Association and a Lecturer in the Faculty of Cultural Sciences of the University of Indonesia in a paper published in the Proceedings entitled Cultural Values in the Seloko of Jambi Malay Customs as a Teaching Material of Local Content of Culture in Middle School, stated that traditional philosophy seems simple, but actually it is very fundamental in 
understanding and living a harmonious life that brings together top-down, left-right, vertical-horizontal harmony.

From several research articles which contain the results of the research of several researchers, it can be assumed that the traditional art of the archipelago has ethical and moral values that function as a system of life as a nation and a state so that it can lead to a good work ethic and character for them. The playing songs are a cultural heritage of the Indonesian people who in the past were very familiar in the environment of children. For some people the playing songs have no meaning, form and function. So the playing songs are game songs devoted to children.

\section{METHOD}

The study was conducted on 2 tribes in North Sumatra, namely: Batak Toba and Batak Simalungun, which are in the Regencies of Simalungun and Toba Samosir, respectively. The population is all the lyrics of the playing songs found in the two tribes. In accordance with the purpose of the study (purposive sampling), the sample was 4 songs each.

\section{A. Data Collection Technique}

Data is obtained from literature studies and semiparticipant field studies. The data from the library is collected as much as possible from the results of previous research reports on primary objects as well as on secondary objects. The primary object in question is a research report that has been carried out on the object to be studied from various disciplines. Secondary objects are research on the art of music and oral literature that have been conducted by previous researchers.

The field study is carried out by gathering children, asking to play while singing, viewing, observing, and documenting in videos and photos. Next the researcher will interpret the meaning of lyrics of the playing songs. A cultural approach is taken to obtain data from the community through participatory. Deep interviews are conducted to find out as much detail as possible the values of moral and ethical philosophy in the songs.

\section{B. Research Instrument}

The research instruments or tools carried out are in the form of documentation of video recordings and photos of each of the children's activities while playing. Unstructured interviews with the aim of obtaining as much verbal data as possible from various parties such as children, traditional leaders, academics and leaders of clan assemblies who are able to explain at least about philosophical values information in lyrics of playing songs.

\section{Data Analysis}

The collected data are grouped according to their respective interests and then analyzed using the Hermeneutics method. The steps in applying successive analysis methods in accordance with Kaelan's opinion [17] in his book Qualitative
Research Methods in the field of Philosophy are as follows: 1) data reduction; 2) data classification; 3) data display, and 4) make interpretation and make decisions [18].

Verstehen method or comprehension [19]. Explanations are always contained in understanding in line with the fourth stage of interpreting to understand the symbolic meaning, namely the data collected is a fairly long description. The researcher understands the meaning of parts or elements that are collected in the study.

\section{RESULTS AND DISCUSSION}

From the results of field research by participating, it was learned that the playing songs of children of the Batak Toba tribe were more diverse than the Batak Simalungun tribe. The existence of the playing songs of the Batak Toba tribe is still maintained and developed with the effort to hold a "martumba" competition every year. Not so with Simalungun, so rarely found the playing songs sung by children of the Simalungun tribe. However, there are still Simalungun songs contested when there is a cultural party of Rondang Bittang in Simalungun Regency. The playing songs of the children of the Batak Toba tribe are no longer sung on the full moon but have become daily games at school and in the village. From the results of interviews with parents, teachers and children themselves, they generally do not really understand the meaning of poetry sung. This proves that there is concern from the school, parents and local government, but the meaning of the poem needs to be taught so that the values contained in it become habits in their daily lives.

Through poetry that is sung repeatedly will make children absorb its meaning so that it can motivate children and eventually become a habit. Children's games are usually in groups and each one plays while singing.

Songs contain values such as: the value of education, the value of togetherness, and human values. The following is a lyric of a playing song of children of the Batak Toba tribe:

"Tangan do botohon da inang, ujung nai da jari-jari da amang. Jong-jong hami dison da inang, jumolo hami marsattabi da amang.

Sattabi da amang, sattabi da inang”

(The hand is a member of the shoulder, the tip of it is the fingers, we are stand here yea... mother, we are first apologize, yea... dad. Please forgive us, yea... dad, yea... mother)

The opening verse of the song and the game starts with the word sorry, meaning the children first say the word apologize if they will start the game and if there is a mistake later, both the speech and the movement of the limbs as a whole. After apologizing, then continue with the second song.

The second song is quite simple but has the spirit and motivation values entitled Hehe which means "Arise"

"Hehe maho da inang, hehe maho da amang Hehe maho da hasian, marembas marhaliang 
Hehe maho da inang, hehe maho da amang

Hehe maho da hasian, unang adong na lemba"

The meaning of this song is to invite everyone, both men and women, young and old, as well as those who are loved to rise up not to be lazy (unang adong nalemba). Get up together, work, dance around and no one is silent. This song motivates the spirit of work, rises from lazing or sitting idly by.

After this song was finished sung repeatedly 2 to 3 times then continued with the song 'Jambatan Tapanuli'. This song was sung while lining up, each holding the shoulder of a friend in front of him, when almost arrived between two people who raised their hands while making a goal shape, they ducked past the two pairs of hands that seemed to enter the hall, which is why it was called the Tapanuli Bridge. The word 'Tapanuli' only refers to the place where the game was held, namely in an area formerly known as the Tapanuli residency. As soon as the song is finished singing it is a sign that the two people who raise their hands will catch the person who is passing the "hand bridge" by dropping the two pairs of hands. The next song is:

\section{"Marsikkola ahu amang, dohotho ale inang, Unang jolo suru ahu, mangula hauma $i$, ai nametmet dope ahu, dang tarula ahu dope, holan marsikkola do ulaonku natama"}

(I go to school $\mathrm{O}$ father and mother, let me not be told to plow the fields, your child is still small, and I have not been able to do it, only school is a decent job for me).

The meaning of this song is an encouragement to parents so as not to force their children to work in wet fields or dry fields, because the main activities of children are school or studying. This is in accordance with the philosophy of the Batak people who read:

"Hugogope mansari, arian nang bodari
laho pasikkolahon gellenghi,
ai ikkon do sikkola satimbo-timbona
sikkat ni na tolap gogokki
Anokkonkido hamoraon di ahu",

which means (I will still work day and night, to be able to send my child to school, my child must be at school as high as possible as long as I can. My child is wealth for me).

The philosophy of the Batak people is to regard children as wealth for parents. Therefore every parent prioritizes children's school needs rather than other needs. Even parents are willing to be hit by rain, wind and scorching heat as long as their children can eat well and school to the highest possible level. Parents already understand that nutritional needs are important for building children's intelligence. In conclusion, Batak parents prioritize the school needs of their children rather than other needs. This song poem fosters the ethos of educating children who have an impact on work ethic and children's tenacity to study as high as possible. This is evidenced by the many Batak Toba people who tasted the world of education not only domestically but also abroad.
The following is a playing song of children from the Simalungun tribe with the title 'Ija Juma Tidahan' which means "where is the field to be planted".

"I ja juma tidahan boto, tidahan bani juma mu I ja holi pindahan botou, I jon da ahu sonari Jenges ni hata mon da botou megah uhur manangar I juma parmahanan botou Ia nau nungala pari Ijon do ahu sonari, Ijon pe dong do loging botou Loging si dua bulung, Ijon pe dong do doding da botou Bujur ni uhur min dabotou mambalosi hatakku ai Doding ni Simalungun (lagu simalungun)

Jenges ni hatami da botou megah uhur manangar Bujur ni uhur min dabotou mambalosi hatakku ai”.

(Where is the field to plant, where to plant in your field where will my friend / best friend find, here I am now Beautiful words of your friends, happy my heart hears it. How good your heart is my friend, answer my words - In the field where to graze, where to work spend time - Here I am now, here is a tree my friend - Tree with two leaves, there is a melodious song my friend - How good is your heart my friend, happy my heart hears it - Good your heart is my friend, answers everything I say).

The meaning of this song contains good value and hospitality as well as the Simalungun people. Listen to each other and answer each other's communication and greetings with coolness. Respect the other person and feel taboo to interrupt or cut the conversation.

The 2nd song with the title

\section{„Holong mangalap holonge}

Ijon roh do hanami sibiak boru haganupan
Sihol mangalo alo parrohni tondong in $2 x$
Pori adong na hurang pambahenan ni boru mon
Ajari nasiam ma hanami o ale tondong nami $2 x$
Hodong hodong na helpat ida ulang ipadurdur hon
Anggo dong nami na lepak ida ulang iparuhur hon
Holong mangalap holong indo rippuni ganup horja
Tondong simada podah boru simada gogou
Sai horas ma ganupan tondong sonai homa hanami
boru. Sai horasma hita ganupan namartondong
maranak boru.

Love is given love - (here we come, all of you - want to welcome you who we respect - If there is something wrong with your brother - teach us a brother we respect - The drooping stalk must not be broken - if there is a mistake, do not show it - Love gives love, that is the key to work - you give advice, we are the giver of strength - Healthy all my brothers, so do we, my brothers - your brothers - Healthy all of us brothers and sisters) 


\section{CONCLUSIONS}

The singing of children while playing is called the dolanan song (playing song). This is one of the media of character education that is taught orally from an early age. Song poetry contains the values of life philosophy, how they value themselves, others, the environment and their Creator. Verses of playing songs containing simple words, sung repeatedly, easily digested and sung as accompaniment for children's games. The simplicity of the word in the lyric turns out to make it easier to be sung repeatedly with the aim to instill these values in the memory of children. Thus, it is expected to become a habitus in everyday life so that all children's activities are based on these values as guidance and order of life to respect human values, the environment and divinity.

The values contained in the lyrics of playing songs of children from the Batak Toba and Batak Simalungun tribes are the values of cooperation, responsibility, respect for parents, education, manners and self-motivation. One of the typical motivational values for the Batak Toba people is that they do not want to be dragged into sadness, but sadness will soon be replaced with songs, therefore many Batak Toba songs with sad poetry are called andung-andung (mourning songs).

The results of the research in the form of the values of life philosophy of the two ethnicities will contribute to strengthening the values of the nation's character and work ethic derived from the local wisdom of North Sumatra. A strong nation is built with the great character of the people whose character values are excavated from the local wisdom of the tribes themselves. These values must be cultivated and applied to life starting from childhood. Later with good character and morals will produce a reliable generation, so that the state becomes strong.

\section{REFERENCES}

[1] Said, Moh, Pendidikan Karakter di Sekolah, Cetakan I, Jaring Pena, Surabaya, 2011, pp. 1.

[2] Hasan, Hamid, Said dkk., Pengembangan Pendidikan Budaya dan Karakter Bangsa, Kementerian Pendidikan Nasional Badan Penelitian dan Pengembangan Pusat Kurikulum, Jakarta, 2010, pp. 3.

[3] Damayanti, Indah, Pendidikan Karakter Melalui Karya Sastra: Sebuah Pendekatan Dalam Pengajaran Bahasa, Prosiding Seminar dan Rapat Tahunan (Semirata) BKS PTN Wilayah Barat Bidang : Bahasa, Sastra, Seni, dan Budaya, UNJ dan BKS PTN, Jakarta, 2015, pp. 217-222.

[4] Kattsoff, Louis O., Element of Philosophy, Alih Bahasa: Soejono Soemargono, Tiara Wacana, Yogyakarta, 1992, pp. 327.

[5] ---of Soemargono, Tiara Wacana, Yogyakarta, 1992, pp. 378.

[6] Wahana, Paulus, Nilai: Etika Aksiologis Max Scheler, Kanisius, Yogyakarta, 2004, pp.52.

[7] Frondizi, Risieri, What Is Value, Open Court Publishing Company, La Salle, Illinois, 1963 , pp. 5.

[8] Bertens, K. Etika, PT Gramedia Pustaka Utama, Jakarta, 1993

[9] Saragi, Daulat, Pengembangan Tekstil Berbasis Motif dan Nilai Filosofis Ornamen tradisional Sumatra Utara, PANGGUNG Jurnal Ilmiah Seni dan Budaya, Vol 28 No. 2, Juni 2018, pp. 161-174.

[10] --------------, Mengungkap Nilai Pedagogis dan Ajaran Moral yang Terkandung Dalam Makna Ornamen tradisional Rumah Adat Batak Simalungun Sebagai Kontribusi Pendidikan Karakter Bangsa. Laporan Penelitian, FBS Unimed dan Lembaga Penelitian, Medan, 2012, pp. 7071.
[11] ---------------, Inventarisai Jenis Motif dan Nilai Filosofis Ornamen tradisional Sumatra Utara Guna Pengambangan Industri Tekstil Berbasis Corak Ornamen Lokal. Dalam Prosiding Seminar Nasional dan Rapat tahunan BKS-PTN Wilayah barat Bidang: Bahasa, Sastra, Seni dan Budaya, UNJ, Jakarta, 2015, pp. 75-64.

[12] Sulistyo, Tri Edy, Identifikasi dan Implementasi Pitutur Luhur (Budi Pekerti) Tembang Pangkur Sebagai Upaya Pelestarian Budaya Jawa dan Penanaman Pendidikan Karakter Nagi Generasi Muda. Prosiding Seminar Internasional Warisan Nusantara 2012 Indonesia, Universitas Negeri Semarang dan University Malaysia Sabah, 2012, pp. 107.

[13] -----------------. Identifikasi dan Implementasi Pitutur Luhur (Budi Pekerti) Tembang Pangkur Sebagai Upaya Pelestarian Budaya Jawa dan Penanaman Pendidikan Karakter Nagi Generasi Muda. Prosiding Seminar Internasional Warisan Nusantara 2012 Indonesia, Universitas Negeri Semarang dan University Malaysia Sabah, 2012, pp.107

[14] Alif, Zaini Mohammad, , Sistem Tata Nilai Dalam Mainan dan Permainan Rakyat Sebagai Warisan Budaya di Indonesia, Prosiding Seminar Internasional Warisan Nusantara 2012 Indonesia, Universitas Negeri Semarang dan University Malaysia Sabah, Semarang, 2012, pp. 225-228.

[15] Hardiarini, Caecilia, Identifikasi Lagi Dolanan "Desaku: Karya R.C. Hardjosoebrata, Prosiding Seminar dan rapat tahunan (Semirata) BKS PTN Wilayah Barat Bidang : Bahasa, Sastra, Seni, dan Budaya, UNJ dan BKS PTN, Jakarta. 2015, pp. 51-58

[16] Pudentia, MPSS, Kearifan Lokal Sebagai Kekuatan Kultural Membentuk Peradaban, dalam Mengoptimalkan Potensi Kearifan Lokal Dalam Pembelajaran Bahasa, Sastra, Seni, dan Budaya, Penyunting: Totok Priyadi dan Martono. STAIN Pontianak Press. Pontianak. 2013, pp. 17.

[17] Kaelan,M.S., Metode Penelitian Kualitatif bidang Filsafat, Cetakan I. Paradigma, Jogyakarta, 2005, pp. 68.

[18] Bakker, Anton dan Zubair Charis Achmad, , Metodologi Penelitian Filsafat, Cetakan II, Kanisius, Jogyakarta, 1992. pp. 43.

[19] Ratna, Nyoman Kutha, Metodologi Penelitian Kajian Budaya dan Ilmu Sosial Humaniora Pada Umumnya, Cetakan I, Pustaka Pelajar, Jogyakarta, 2010, pp. 316. 